\title{
ENGINEERING ASPECTS OF FAO'S WORK IN THE FIELD OF RURAL AGRICULTURAL INDUSTRIES ${ }^{1}$ )
}

\author{
A. ATEN \\ Rural Industries Specialist \\ Rural Welfare Branch - Agriculture Division \\ Food and Agriculture Organization of the United Nations, Rome, Italy
}

THE IDEA OF INTERNaTtonal MELP

Among several organizations in the United Nations family there is a general agreement that an international interchange of technical knowledge, to combine and make use of the experience of many countries with different social patterns and cultural traditions and at different stages of development, can facilitate progress in the less advanced countries and help solve their technical and economic problems. These words are in the phraseology of the now famous Resolution 222 (ix) which was formally adopted in August, 1949, by the Economic and Social Council and which initiated the Expanded Program of Technical Assistance to promote the economic and social progress of peoples of the world.

The idea of technical assistance at the international level is not new. Nevertheless, the scope and scale of the program now well under weigh is quite unprecedented, and it is still too soon to judge its full effectiveness. Some sceptical people doubt whether it is really possible to narrow the gap between the differing stages of economic and social development in various countries, and these people look upon the advent of atomic energy as a factor more likely to widen than to narrow the gap. There is no need in this paper to debate such a pessimistic outlook. It will be enough to have acknowledged that we are on the verge of another industrial revolution and to emphasize that the benefits which mankind may be capable of deriving from the peaceful uses of atomic energy can be shared by all peoples only if we resolve to maintain and strengthen in a practical manner the international interchange of technical knowledge.

The provision of international extension and advisory services has been an important part of FAO's work in the past ten years, with governments, rather than farmers, as the immediate recipients of its services. As part of this work, FAO collects and distributes a variety of information, including data concerning Rural Industries.

Many methods are used by FAO to assist and advise its Member Governments on the improvement of their agriculture; and the scope of FAOs activities, which are of an advisory nature, is very wide.

The purpose of this paper is to outline those activities of the Agriculture Division which come under the heading "Processing of Agricultural Products and Rural Industries" which is one of the engineering aids to governments and through them to farmers. An up-to-date list of FAO's activities in this particular field is given in Tables 1, 2, 3, 4 and 5 (p. 191-196).

1) Paper presented at the Tropical Agricultural Days, 10 and 11 October, 1955 at Wageningen, Netherlands. 
In order to indicate the place of processing amongst similar activities which are also the responsibility of the Agriculture Division, some other engineering aids to farmers will be mentioned in general terms, before introducing this particular subject.

\section{ENGINEERING AIDS IN AGRICULTURE}

There are in the program of the Agricultural Division a number of activities which call for an engineering approach.

Engineering can be broadly defined as the art and science of utilizing the forces and materials of nature for the benefit of mankind and the direction of man's activities towards this end. Some of the subjects which have engineering aspects, with particular reference to the use of tools, equipment and machinery, are listed below :

1 Small farm tools and animal-drawn equipment

2 Farm power and machinery

3 Machinery workshops

4 Land development and reclamation equipment

5 Irrigation and drainage equipment

6 Water-lifting devices

7 Equipment related to farm and range management

8 Aerial and ground spraying and dusting equipment

9 Rural electrification

10 Farm buildings

11 Farm roads

12 Farm transportation

13 Storage and preservation of agricultural products, cold storage and refrigeration, construction and equipment

14 Processing of agricultural products and rural industries

It must be pointed out however that, owing to budgetary limitations, not all these subjects have yet received adequate attention.

\section{Agricultural processing}

Processing in a general sense, unfortunately, does not receive very much attention in agricultural literature and research, and it is felt that there is scope for much more consideration to be given to this field of science, particularly by those who are basically agricultural scientists.

Some eleven years ago, the term "processing" came into regular use in the Journal of the American Society of Agricultural Engineers (Agricultural Engineering) and since then a few papers have appeared defining the field of activity of agricultural processing.

These articles make reference to some of the characteristics of the newlydefined science and also make an attempt to estimate its potentialities for the future. They were also intended to interest young agriculturists and to encourage them to choose agricultural processing as one of their subjects for study.

Interest in this field shown by agricultural scientists particularly in the United States of America came as a logical development, because during and after World War I a move towards rural industrialisation, farm processing and the preservation of products at home, took place. The availability through- 
out the country of electric power, equipment and machinery suitable for farm processing, the necessity for some decentralization of branches of industry, as well as the increase and movement of population, resulted in the erection and operation of many small enterprises in rural areas.

Some of these small plants are reported to have a unit production as high as, or higher per worker than that of large plants in industrial urban areas.

Agricultural processing may be defined as any processing activity which is or can be done on the farm, in rural areas by individuals or by groups of farmers, processing cooperatives, local enterprises, or enterprises of any type in which the farmer has an active and close interest. More specifically, any farm or local activity which maintains or raises the quality, or changes the form or characteristics of a farm product from the viewpoint of the user, may be defined as "processing".

Agricultural processing has many factors in common with chemical and industrial processing, where the concept of "unit operation" has been introduced to advantage.

An agricultural processing job can also be broken down into a series of specific steps, or "unit operations" and many of these unit operations are common to more than one process. Drying, for example, is such a "unit operation".

A list of some agricultural processing activities, performed on a number of agricultural products, is shown in Table 6.

Table 6 Some agricultural processing activities

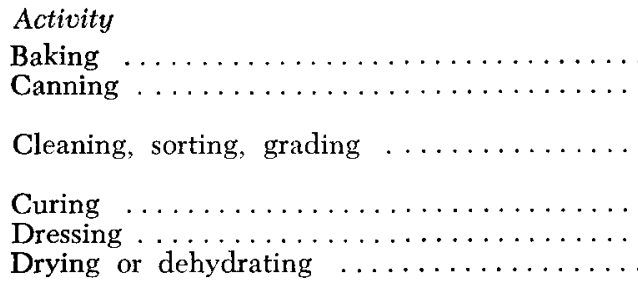

Decorticating $\quad \ldots \ldots \ldots \ldots \ldots \ldots \ldots \ldots \ldots$ Extracting

Fermentation.$\ldots \ldots \ldots \ldots \ldots \ldots \ldots$

Freezing, refrigeration, conditioned storage ....

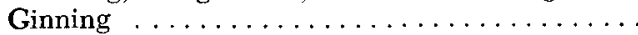

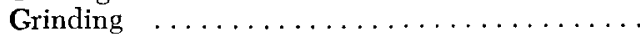

Home pounding, milling

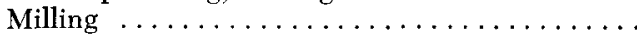

Mixing $\ldots \ldots \ldots \ldots \ldots \ldots \ldots \ldots \ldots \ldots \ldots \ldots \ldots \ldots \ldots$

Packing

Roasting $\ldots \ldots \ldots \ldots \ldots \ldots \ldots \ldots \ldots$

Reeling $\ldots \ldots \ldots \ldots \ldots \ldots \ldots \ldots \ldots \ldots \ldots$

Tanning $\ldots \ldots \ldots \ldots \ldots \ldots \ldots \ldots \ldots \ldots$

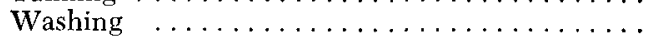

Withering $\ldots \ldots \ldots \ldots \ldots \ldots \ldots \ldots$

Weaving, spinning $\ldots \ldots \ldots \ldots \ldots \ldots \ldots \ldots$

Transportation, handling $\ldots \ldots \ldots \ldots \ldots \ldots$

Other activities
Material

Flour

Fruit, fruit juices, jams, fish, meat, peanut butter, vegetables

Cotton, eggs, fibers, grain, seeds, nuts, fruits, vegetables, wool

Fish, hides and skins, tobacco

Meat, poultry

Cotton, coconuts, dates, grass, grain, forage, fish, hides and skins, seeds, paper pulp, rubber

Fibers

Bark (vegetable tanning extracts), fish, flowers and grasses (essential oils), oil seeds, sugar cane and beet

Tobacco, tea, wine

Meat, vegetables, fruit, potatoes

Cotton

Animal feeds, fish meal, olives, cassava roots

Grains

Rice, wheat, sorghum, maize, sugar cane, rubber

Animal feeds, fertilizers, insecticides and fungicides

Fruits, vegetables

Coffee beans

Silk

Hides and skins

Fruit, eggs, vegetables, wool, hides and skins

Tea leaves

Coir, fibers, cotton, silk

All agricultural products

Processing of butter, cheese, honey, rubber 
It may be difficult sometimes to determine whether a specific job is agricultural or industrial processing.

Whether there is a clear cut difference or not, is a point of academic interest, and a decision can be made easier by taking into account the qualification "in which the farmer has an active or close interest".

In any case, the definition mentioned above, for which credit has to be given to Professor S. M. Henderson, W. M. Hurst, and others, contains an essential guiding principle, that can be of great help to those who are engaged in assisting and advising on programs of rural agricultural industrialization in the so-called less developed areas.

In these countries, the farmer grows his crop by the "sweat of his brow" and an additional income for his family, so very much desired, can be derived when he is enabled to make extra profit by processing, or partially processing his own crop.

Such a development at a later stage will also be of great advantage, as it will not be so easy to make an artificial separation of agriculture and industry, particularly in countries which have predominantly an agrarian econorny.

\section{RURAL INDUSTRIES}

It is a well-known fact that food preservation on the farm is a very old practice, much older than the urban industrialised processing of farm products. Although the historical development of primitive rural communities has not everywhere followed the same pattern, it seems that processing activities, except on the farm and at home, did not exist in such self-contained communities, based on subsistence farming, as there were no agricultural surpluses.

In a later phase of development, through improved methods of agriculture, somewhat higher rates of production were created resulting in agricultural surplus, such as grain, meat, fish, salt and timber, which were exchanged among members of the community. Later on, recognised markets were instituted for the exchange of surplus commodities, and money came grodually into general use.

As a result, a small proportion of the rural community became specialised in marketing of food and other primary products.

In this pre-industrial period, however, there was no elaborate transformation of raw material, no machines were used nor paid labour employed.

Gradually, however, the way was paved for some other members of the rural community to be fully employed in activities such as the processing, transformation and manufacture of primary materials. It may be generally assumed that people worked in the beginning in the family as individuals and later on as organised groups, in cooperatives, or as contracted wage earners. In this way, the rural community gradually emerged from primitive subsistence farming through the commercial stage into an industrial stage.

Activities in the "industrial" stage were based on the utilization of locally available raw material, and gradually comprised such occupations as the milling of rice and other grains, the extraction of vegetable oils, the curing of hides and skins, fish and meat, the processing of vegetable fibers, the preparation of timber and the smelting of ore.

In a later stage of evolution, materials were transformed, as, for example, grains into bread, hides and skins into leather, fibers into clothes and timber into furniture. 
In the final stage, the manufacture of equipment, material and capital goods was established, not to satisfy direct needs but to facilitate the future development of production and processing.

It should be recognised that the above break-down is useful only as a rough indication of the historical development, but actual facts present a much more complex picture.

As the initial natural development of rural industries was dependent on the availability of sufficient and suitable domestic raw material, the number and type of activities cover a very wide field, and several attempts have been made to define or encompass the scope of these activities.

Terms, such as village industries, farm industries, handicrafts, cottage industries, small-scale industries, and so on have a certain appeal and flavour and are useful on special occasions, but preference is given to the collective noun "Rural Industries", particularly when applied to less advanced areas, as it is self-descriptive. It needs, however, to be defined further and several definitions have been proposed, such as "an activity in which the predominant manpower resides on the farm, and where modern technique and technology is applied to fabricate, process, or otherwise transform products into a more finished state" (C. J. Hurn).

The Committee on Agricultural Industries of the American Society of Agricultural Engineers, has advanced the following definition "From an engineering viewpoint, agricultural rural industries and services may be defined as any enterprise where engineering techniques are applied in preserving or changing the form of agricultural products ; in assembling, preparing, packing, marketing and transporting agricultural products, and in processing or manufacturing materials and supplies for farm use". Whatever criticism one may make, this definition is attractive because again the farmer, and in addition the engineer, the farmer's technical helper, is placed right in the centre of the picture.

\section{The Place of ENGINEERS IN RURAL INDUSTRIES}

In the very wide field of the processing of agricultural products, especially in larger industries, which can afford to appoint specialists, mechanical and chemical engineers, as well as food technologists, are widely employed.

Obviously, this type of engineers are also capable of helping in improving conditions in rural areas by introducing new techniques, which can be made acceptable by practical field demonstrations or pilot demonstration plants.

However, it is felt that there is a need for specialised training of the particular type of engineer called upon to deal with processing in rural industries, fostering rural industrialisation projects with particular reference to less developed areas. He could well be termed an "agricultural processing engineer" and some of his qualifications will now be discussed.

Primarily, he should have the right type of character, necessary for one who is to live in rural areas and to work with farmers, whose confidence he must gain. Farmers all over the world have their particular social and economic "philosophy". In order to define the nature and the scope of the problems confronting the farmer, the engineer (under consideration) should study rural sociology and rural agricultural economy. (Some further thoughts regarding the farmer, with particular reference to tropical and sub-tropical rural areas will be discussed later). 
In addition, this engineer should be an all-round agriculturist, familiar with tropical and sub-tropical crops and the climatic and soil conditions under which such crops are grown.

His education should be supplemented with studies in some special branches of engineering, practical training in mechanical and some chemical engineering practices and last, but not least, he should study processing jobs in general, while specialising in a knowledge of certain methods.

It is fully recognised that an engineer with these qualifications would be a sort of "miracle" man. However, he will obviously be in a better qualified position than his colleagues to advise on agricultural crops, which, particularly in less advanced areas, do not receive adequate attention in the pre-processing stages, and no processing will improve badly treated domestic raw material.

\section{THE FARMER CLAIMS OUR MAIN INTEREST}

It is not intended to present here an exhaustive study of the advantages and disadvantages of rural industrialisation, but it is clear that the farmer will primarily claim our interest, for industrialisation is not an end in itself but aims, together with simultaneous and synchronous development of agriculture, to raise the average standard of living.

In the past, industrialisation caused a complete change in the social pattern of communities in the western world. Deeply rooted social and religious traditions were often disrupted, without being replaced or adjusted to the needs of the new communities in many cases. Social evils resulted, and the term "industrial proletariat" came into being.

There is no reason for a repetition of such errors in less developed countries to-day. However, some of the countries concerned could present similar difficulties, and these must be faced.

In vast areas of Asia, the Near East, Africa and Latin America, where about three-quarters of the world population is living in rural societies, the farmer receives his income, which is generally very low, from the land and the greater part of the income is spent on food.

Farmers cultivate their crop as part of a social pattern, governed by unwritten social and often religious laws. The farmers dominate their society, and many who are not farmers provide services for the farmers, which makes them directly dependent upon farming income.

In these regions, mainly with semi-tropical or tropical climates, crops are usually cultivated on very small holdings during five, six, or sometimes seven months of the year. During the remainder of the year the farmer finds little or no productive employment on the farm.

This, however, does not mean that he is lazy, and he himself certainly does not consider it as idleness. The days when he does not work are considered as holidays rather than as days of unemployment. He has no difficulty in occupying his time, there are always marriages and births to be celebrated, and deaths to be mourned, and on these occasions the farmer is fully occupied because this is required by the unwritten social laws of the community in which he lives. In these communities the elders, sometimes elected, sometimes attaining their exalted position through age, inheritance or personal influence, perform many of the official duties. They settle disputes, deal with crime, allot land, are responsible for the upkeep of the village temple, church or mosque, 
control the relationship between village craftsmen and services, and, in general, are the leaders of their people.

It is clear that in such a community, where customs are old and strong, great powers of resistance against any form of modernization have to be surmounted. Obviously, the primary task of economic development in such areas should be the increase of agricultural production, and of efficiency of production, followed eventually by improved handling, storage and processing to avoid unnecessary losses.

There are other points that have to be mentioned in this connection, namely the lack of industrial-minded capital, and organizing ability, lack of technical knowledge and of skilled operators.

Therefore, to conclude, a move towards industrialisation cannot be expected unless governments take the initiative in encouraging and fostering existing industrial nuclei and opening up new possibilities based on local conditions, with particular reference to better use of local raw material. Government officials must be convinced that their farming communities should be mobilized.

This is particularly true if those who are rural leaders, responsible for guiding rural communities towards the goals of industrialization recognise what can be established through improved processing of agricultural products and rural industries.

And it is here that international specialised agencies, such as FAO can be of great help through their programs of technical advisory assistance.

The ROLE OF FAO

FAO has been helping its Member Governments in many ways, and two of them will be discussed briefly: these are the dissemination of technical information through agricultural development papers and agricultural studies, and direct technical advisory assistance.

Agricultural development papers, some of which deal with the processing of agricultural products and rural industries, are primarily intended for rural leaders in those countries where the science of agriculture is not yet highly developed, and who are, or will become responsible for guiding the programs of agricultural rural industrialization.

Through the medium of these series of papers, dealing with equipment for the processing of a number of agricultural products, improved techniques and the application of modern technology in rural industries, rural leaders are shown how improvements in a certain field are made feasible.

Although it cannot be expected that progress will become apparent immediately after the publication of such papers, undoubtedly, the seeds of development are sown the moment rural leaders learn of improvements which can be effected, thus paving the way to the possibility of adapting them and of requesting direct technical advisory assistance in their development.

If development follows these lines, it can be said that FAO's "Regular Program" and "Expanded Technical Assistance Program" are supplementing each other.

It is interesting to note that, although these papers are primarily intended for rural leaders in less developed countries, some of them are adapted to use as simple textbooks on technology in agricultural schools and colleges and by workers who are responsible for the supervision of certain processing activities. 
When preparing development papers, describing the equipment and machinery which is available on the world market, it has to be realized that some types are not entirely suitable for use in under-developed countries.

FAO is very carefully developing contacts with manufacturers all over the world and it is encouraging to realize that there is an increasing interest in designing and manufacturing equipment and machinery for processing which can be adapted to conditions in less developed areas.

It is hoped that the time will come when appropriate equipment and machinery can be supplied at reasonable cost by manufacturers who have sufficient imagination to realize that a vast potential market can be developed once these extensive rural areas are opened.

FAO is in the fortunate position, once a program of direct technical advisory assistance has started, to help member countries by making available supplementary equipment and machinery for use in demonstration centers, pilot plants and so on.

From the foregoing remarks on equipment and machinery it will be understood that much still remains to be done, and it is highly desirable that there should be further interest and study in this field by engineers working in experimental stations and in fundamental research, and by private manufacturers.

Before giving further details of some specific FAO projects carried out in the field of rural industrialization, it might be useful to say something about the working relationship between an expert in the field and his counterpart, his subject-matter officer, at Headquarters.

\section{SERVICING OF FIELD EXPERTS}

Field Experts, appointed under FAO's Expanded Technical Assistance Program to provide technical advisory assistance to Member Governments, have definite terms of reference. They are expected to be fully conversant with the work to be done, and have a thorough knowledge of similar problems in their own countries, where they quite often have held senior positions in Government of private industry.

However, the religious and social pattern and the climate of the country of assignment usually differs from that to which the field expert has been accustomed, and it is not surprising that occasionally he "gets lost".

To ensure, as far as possible, that the expert is prepared for the difficulties a head, he is given a short briefing at FAO's Headquarters. During this time he discusses general problems related with his work with various specialists and establishes relationships particularly with his subject-matter officer, whose duty it is to initiate him into the specific requirements of the assignment.

Much emphasis is laid on the establishment of good working relationships between the field expert and his subject-matter officer at Headquarters the responsibility for the development of the program being thus divided.

They maintain close contact through correspondence and monthly reports, and on suitable occasions, the subject-matter specialist from Headquarters visits the expert in the field, or the latter may be called to Headquarters for consultation. Any important programs or policies are referred to Headquarters before they are submitted by the field expert to Government officials in the country of assignment. 
The field experts' final reports are prepared in the same spirit of mutual cooperation, and recommendations as well as reports are cleared at Headquarters before being submitted to the Governments as FAO's final recommendations.

It is obvious that such a close working relationship has great advantages and ensures efficiency and the maintenance of common lines of policy. The expert in the field does not feel "alone" and Member Governments have the assurance that the work will progress smoothly and harmoniously, while FAO, fully sharing the responsibility, ensures that the program's development is acceptable to the country, economically and socially.

There is naturally created a "cross-cultural" situation, when specialists of another nationality and often another race, with different cultural and religious backgrounds, are assigned to advise and assist less advanced countries.

This is fully recognised as unavoidable, and therefore has to be accepted, but much wisdom is required by experts in the conduct of their assignments.

It is clear, therefore, that great care must be taken to avoid harmful and sudden changes, as rural culture is a closely integrated whole, and attempted changes in any part of it will certainly affect the whole. Family and community life should therefore be left untouched as far as possible, leaving the introduction of modern innovations gradually to change rural patterns.

This is equally true with regard to the introduction of modern techniques, equipment and machinery, and it is therefore highly desirable to base improvements on local existing circumstances, carefully studied beforehand and so arranged that farmers can accept and adopt the improvements step-by-step.

Certain recommendations, in themselves in a strictly "technical" sense fully justified, may cause a complete change in the customs and habits of the people concerned, and such a "social revolution" may be detrimental.

The danger of too rapid rural industrialization has in this respect already been mentioned. In some of the following "case histories", the step-by-step system of introducing improvements, will be outlined.

\section{FAO'S PROJECTS ON THE IMPROVEMENT OF HIDES AND SKINS, TANNING AND LEATHER}

Hides and skins are very important commodities in which there is an enormous world trade. FAO has been actively interested in this subject and Agricultural Development Paper No. 13, dealing with tanning equipment, was published in December 1951.

Since then direct technical advisory assistance has been requested and given to a number of Member Governments, as listed in Table 7.

Table 7 Member Countries to which direct Technical Assistance in the field of hides and skins and related matters has been given or is planned.

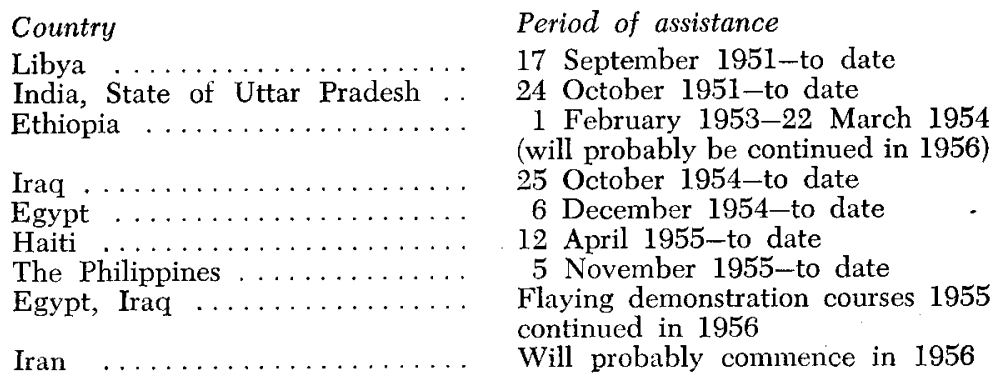


Furthermore, FAO issued in May 1955 a new Agricultural Development Paper, No. 49 entitled "Flaying and Curing of Hides and Skins as a Rural Industry". In this paper, the experience of many field workers engaged by FAO, as well as that of employees of various Governments, organizations and private companies, has been brought together.

These projects have been remarkably successful, partly due to their specific technical nature which does not necessitate any costly capital investments in order to make improvements feasible. The way such an improvement program can develop step-by-step, will now be described in greater detail.

\section{Step 1 - Flaying}

In a number of countries, proper flaying and slaughtering techniques are practically non-existent, thus causing considerable damage to hides and skins right from the beginning. This is usually not because the flayer is unwilling to work well, but because he has never been taught how. There is, therefore, no incentive and it is not realized that, with a little more care and skill, the flayer could earn more for himself and ensure for his country higher prices for the commodity.

First-grade hides and skins must reach a certain required standard: without flay-cuts and having a regular and symmetrical shape.

The first job of a field expert, after he has studied local conditions of work is, therefore, to aim at improved slaughtering and flaying.

This preferably should be done through practical demonstrations, introducing and encouraging the use of well-designed knives instead of indigenous and unsuitable tools. As these knives are neither complicated nor costly, they can eventually be produced in the country by any local blacksmith.

In recognised slaughterhouses having a sufficient daily production, the introduction of mechanical flaying machines may also be considered.

A specific problem which regards the field expert may be mentioned here. It is clear that such an expert has to be recruited from among people whose level of education and ability is sufficient to enable him to handle the whole program, including new legislation, improved marketing arrangements and practical demonstrations. A professional butcher, who would have the necessary qualifications which are required in the initial phase of the project, i.e. flaying demonstrations, would not, as a rule, have those extra qualifications necessary to cover the whole of the project.

It is felt therefore that for some months an experienced flayer, such as a foreman from a recognised abattoir of high reputation should be attached to the field expert. Additional flaying demonstrations are now being inserted in the programs for Iraq and Egypt.

\section{Step 2 - Curing}

Hides and skins, when they are removed from the carcass, particularly in hot climates, are subject to rapid putrefaction as they are easily attacked by bacteria and mould.

Dust, dirt, soil, water, blood, manure and so on act as continuous sources of infection, quite apart from the transmission of micro-organisms through air, insects, or contact with diseased animals. It is therefore necessary to cure the skins in order to preserve them. 


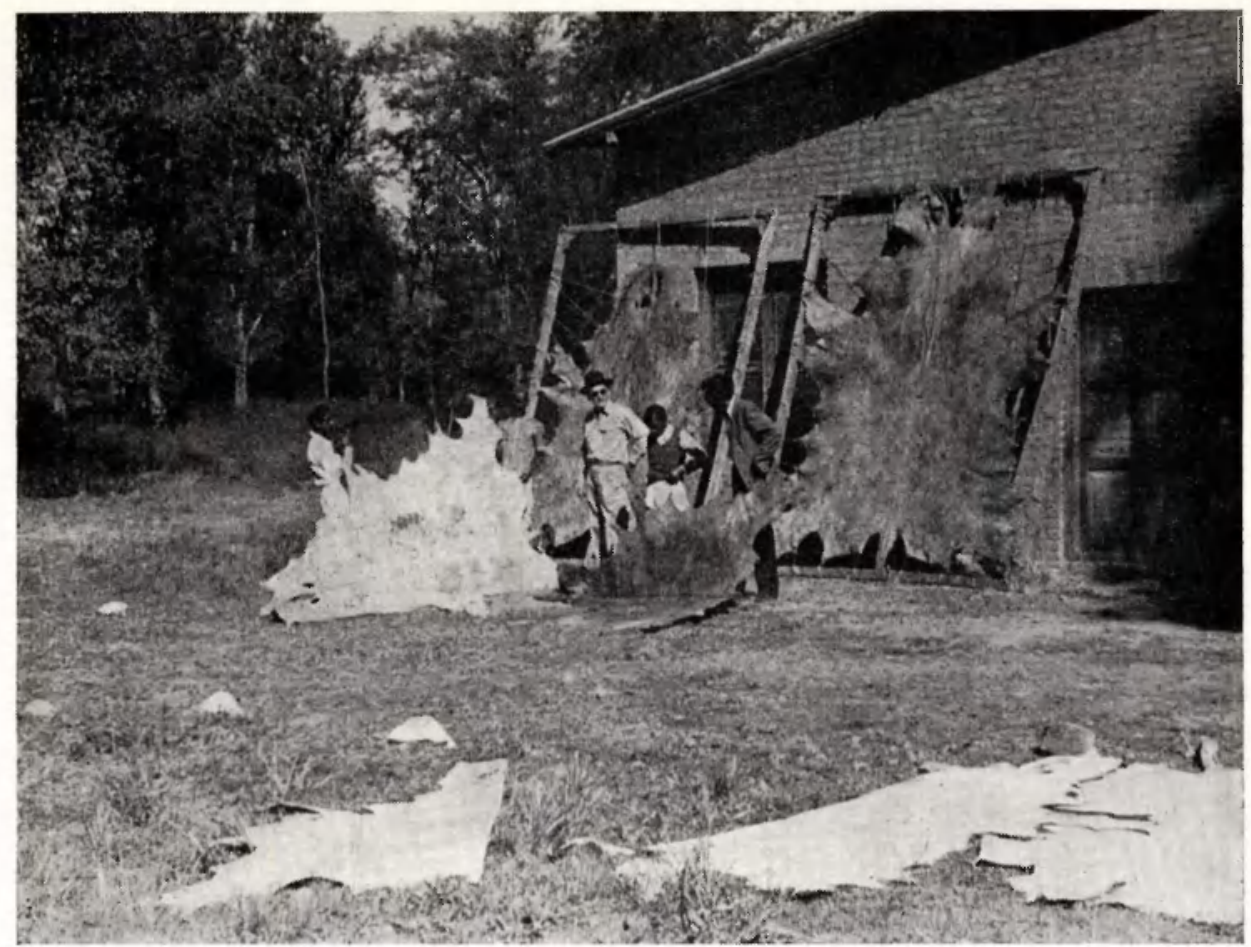

Fig. 1 Frame drying of hijes in RURal Centre (India U.P.)

The essential point is that hides and skins must be washed and dried without delay, and this is carried out by one of three methods :

a air-drying

b salt-curing

c pickling

It is not intended to go into further details which, on the other hand, can be found in Agricultural Development Paper No. 49.

Practice has shown, that through practical demonstrations conducted by field experts, great improvements, often resulting in even lower operational costs, can be quickly achieved.

\section{Step 3 - Grading, Handling, Transportation}

Hides and skins which have been well flayed and cured have to be graded, handled and transported with care, in order to ensure that they fetch the highest prices on the market. Very often hides and skins are badly handled, and are sold by weight, with mud, dirt, and part of the hooves and horns included. This state of affairs must be changed, in spite of stubborn resistance on the part of the merchants, but no lasting results will be achieved unless higher prices are paid as a reward for the greater care taken.

Experts have often experienced great difficulties in persuading tanners, merchants and hide dealers to pay more for the improved raw material, and 
as merchants and dealers usually have their own trade agreements, it is felt that in some cases groups of slaughterhouse workers could be encouraged to get together and operate their own curing yards, and, eventually, trade their own skins. (This may be possible in Tripoli, Libya).

This will also ensure that, when better work is done, the lower groups of workers will receive extra pay and share the profits.

\section{Step 4 - Organizational matters, Testing and Research Institute}

Once a program has been launched, it is desirable to investigate the question of simple legislation, as it has been done in Libya, Ethiopia, and Egypt. Under the new Libyan law, the position of the flayer, who is liable to lose his certificate (licence) through continuous bad flaying, was defined. The same law established standards for the grading of hides and skins, thereby ensuring that slaughterhouse workers received a bonus for better work. Such legislation is, however, useless unless there are instructors and inspectors to establish an extension service. It is necessary to recognise that, in any hides and skins improvement program, flayers are the most important workers, and that a continuous production of good hides and skins cannot be ensured, unless there is a permanent staff of instructors for flaying and curing, hides and skins improvement officers, and some senior officers for the guidance and supervision of the whole program.

Salaries in such a Government-sponsored improvement program, should be sufficiently high to attract the most suitable type of man and should provide opportunities for advancement to young men who wish to make it their career.

As soon as such an extension service has been organised, with a sufficient number of officials to carry out the work, an Institute could be established to examine and test raw domestic materials and finished leather, and to do research work in this field, including the utilization of domestic vegetable tanning materials.

Primarily, the Institute should not aim at basic scientific research, but at experimental work on a practical level, with the object of assisting extension workers whose job it will be to supervise and guide local rural industries.

\section{Step 5 - Tanning}

Once raw domestic hides and skins are produced in sufficient quantity and quality, the next step is to tan them for local use, and, provided the quality is satisfactory, for export. In most areas where raw materials are produced, tanning is known since ancient times, but needs to be improved. As it will be seen further on, use can be made of domestic vegetable tanning material, either alone or together with chemical processes, such as, for example, the combined vegetable chrome tanning process.

\section{Step 6 - Leather, leatherwork}

Leather work techniques, manufacture of leather goods, shoe making etc., based on existing local conditions have to be improved or to be introduced where needed.

At this stage, the Testing and Research Institute referred to in Step 4 can be used to advantage. 


\section{Step 7 - Utilization of By-Products}

Utilization of by-products, such as blood, condemned carcasses, bones, hooves, hair, glands and so on, is an important part of the program, as additional profits may be derived by it.

Although many of the techniques used in advanced countries need to be simplified and adjusted before being used to advantage in rural areas, still some progress in this field has already been made in several countries; however, much more remains to be done.

It is believed that it is not possible to define an improvement program which would be suitable for all areas concerned. Experts in the field have to make a careful study of local conditions before a complete program can be launched. The above mentioned step-by-step program, however, has proved to contain useful essential principles which, provided they are adjusted to existing local conditions, give sufficient background for the establishment of a country-wide development program.

Most of these stages are covered in the program of technical advisory assistance submitted to the State of Uttar Pradesh in India, which has been one of the first countries to come under FAO's Program of Technical Assistance.

\section{The deVelopment program In India, State of UtTer pradesh}

Mr. F. H. Hozk, who comes from the Netherlands and is a graduate of the Leather College in Waalwijk, was appointed to advise and assist the Government of the State of Uttar Pradesh and he developed the program more or less along the lines mentioned before.

One-fifth of the world livestock is found in India, but their value is seriously affected by the shortage of fodder, the great number of non-essential cattle, and the low level of education of the small farmers.

Most of the States of the Indian Union have banned the slaughter of cows and their progeny, and only old and useless buffaloes are allowed to be slaughtered, hence the expert is faced with the tremendous problem of the "fallen" animal and the improvement of the quality of "fallen" hides.

Fallen hides are derived from carcasses found in the vast plains of India or urban areas. It is obvious that an animal which dies a natural death is exposed to putrefaction immediately after his death, and even during the sinking stage, animals are worried by vultures and dogs. Permanent damage to the hide can be caused when flaying is not carried out immediately after the natural death of the animal. Blood remains in fallen hides, with the result that these hides are more liable to putrefaction than hides from slaughtered animals.

Flaying of fallen hides, moreover, presents a separate technical problem, as it has to be carried out in the open, without shelter, water, flooring, hoisting equipment, transport facilities and so on.

Then there is the social problem. Since ancient times flaying has been done by a certain class of people, called "chamars" belonging to the lowest group of Indian Society, and our expert, with assistance of Indian nationals, had to work with the particular interest of this class in mind. Fallen hides never commanded good prices in the past, partly due to the above mentioned faults, 
but mostly due to untimely flaying, defective take-off and unsuitable curing methods.

Initially, with the help and cooperation of officials belonging to the Animal Husbandry Department in Lucknow, efforts were made to demonstrate on a small scale the possibility of improving fallen hides. This led to the establishment of a training center at Bakshi-ka-Talab, a small village located about 12 miles from Lucknow. At the same time, in order to ensure a regular supply of raw material, a carcass-lifting scheme was put into operation. At present, not a single dead animal is found uncared for in Lucknow, as the Animal Husbandry Department is extending its free services in lifting the carcasses of the cattle owners. The carcass-lifting flying squad stands by to remove carcasses for the bènefit of the general public and of the center.

Already more than 200 persons have received training, mainly in improved methods of flaying and curing of fallen hides. The trainees, after successful conclusion of their period of study, receive a certificate and return to their rural districts where they train village workers.

The center in Lucknow is provided with all the necessary equipment, while the Animal Husbandry Department have also installed a pressure cooker for the processing of sterilized meat and bonemeal, which serves as feed for poultry and pigs and for manurial purposes.

A training course in tanning has also been established, and these trainees will in the future have to guide a great number of rural tanners with regard to the adoption of improved tanning techniques. This center, the first of its kind in India, and now becoming a pilot type, is fully able to convert fallen animals into valuable products.

It should be borne in mind, however, that the introduction of these modern technological methods creates social problems. In the beginning only "chamars" were attracted to this training, but gradually young people of higher social groups also joined the center, and graduates from colleges have already finished their training and are now working successfully as supervisors in rural hide development work.

When the writer visited this center towards the end of 1954, it was encouraging to find an enthusiastic group of workers who properly flayed, cured, handled and stored fallen hides of outstanding quality.

A number of similar centers are now in operation in the State of Uttar Pradesh, their size varying according to local conditions, but all using the same improved techniques.

These centers have already managed to attract over 900 village flayers, and hundreds of sets of flaying tools and wooden drying frames have been distributed among the trainees in the rural areas.

It is encouraging that the village flayers who now are in regular contact with the hides improvement supervisory staff are no longer waiting for tools and equipment offered free of cost by the Government, but they manufacture them themselves, following approved patterns.

This is a clear indication that the poor village flayer has realised the importance of improved techniques.

The Government of Uttar Pradesh has allotted a generous sum of money for the whole development program, as shown in Table 8 . 
Table 8 Progress in the field of hides and skins improvement and related matters in the State of Uttar Pradesh (India) - see also map, p. 190.

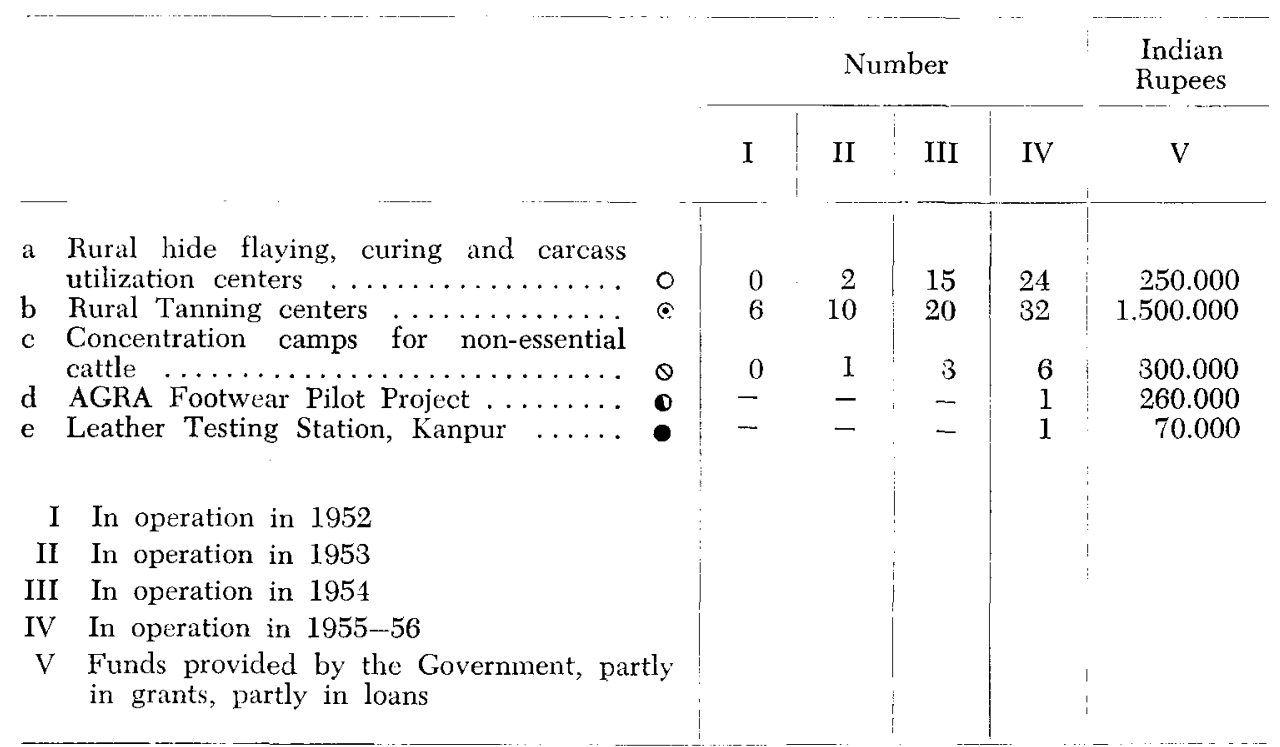

Note. FAO contributed to this program $\$ 8.000-\overline{\text { for }}$ equipment, mainly on tanning.

The established centers are self-sufficient and most of them are making a profit. It has been found that a well-flayed and properly cured fallen hide can easily fetch 4 Rupees more than an ordinary one. The above mentioned trained village flayers can produce at least 60,000 well-flayed and cured fallen hides per year, thereby increasing their gross total income by about 240,000 Rupees.

Another sign of progress in a commercial sense is the fact that large hide merchants and dealers are becoming more and more interested in the improved methods, as well as in the final products of the rural industries centers.

In fact, hide merchants who exported before the war thousands of air-dried or dry-salted hides, could not understand how the improved hides could be derived from fallen animals. Their whiteness and brightness was such that the remark was made "these hides look as if they had been washed by a washerman".

The rural tanning centers also make good progress. Formerly, the village tanner had his own primitive establishment, using earthenware pots sunk into the ground, without covers and outlets, resulting in under and bag-tanned leathers of low quality.

These village craftsmen are now organised in a cooperative tanning center, located outside the village, equipped with suitable tanning pits, drums, barkcrushers, adequate water supply, storage space and so on, while in some centers even sole leather rolling machines are installed.

The chrome vegetable tanning process has been introduced, reducing processing time by over 50 percent, and producing excellent sole leather which can compete in price and quality with that produced in bigger mechanized establishments.

The village tanners, naturally, were in the beginning sceptical but are at 
present full of enthusiasm. There are no bad smells in the rural hide producing, curing and tanning centers, and the villagers are proud to show their centers and clean villages.

Shoemaking has been a rural industry in Agra since time immemorial, and nowadays about 30,000 people are engaged in this industry and other leather work. The quality of the work has deteriorated, because after Partition many skilled workers left for Pakistan.

However, a training center has been installed here and a small last-copying machine has been set up in the Government Leather Working School at Kanpur to train operators in producing lasts suitable for Indian feet. The Agra shoe pilot project is now producing shoes of a good quality at extremely competitive and attractive prices.

\section{FAO'S PROJECTS IN DATE PROCESSING AND PACKING}

Direct technical advisory assistance in this field has been given to the Governments of Saudi Arabia, Libya, Iraq and the Sudan, while Pakistan is in the program for 1956.

In their natural state, dates have to be considered as a perishable food, because their sugar and moisture content, 58 to 60 percent and 28 to 30 percent respectively, render them non self-preserving.

The consumer, however, will regard them as fresh fruit with the keeping qualities of dried fruit. Therefore, although a buyer will take for granted the spoilage of a fresh peach or apple, he expects a date to retain its characteristics indefinitely.

Commercial dates, which are protected from insects, do not fall into the perishable category, and will keep for about a year, with only slight deterior-

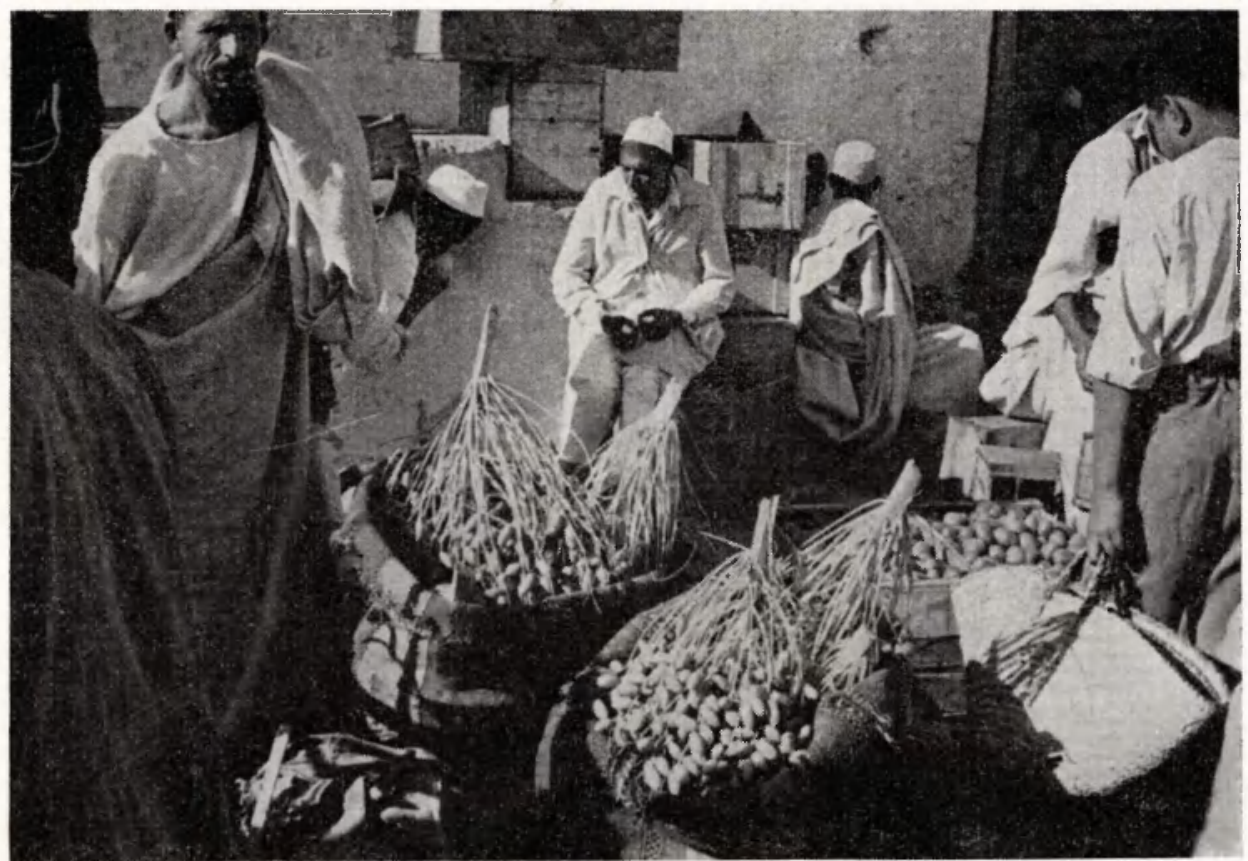

Fig. 2 Iminatule dates as they arrive at the market in Libya 


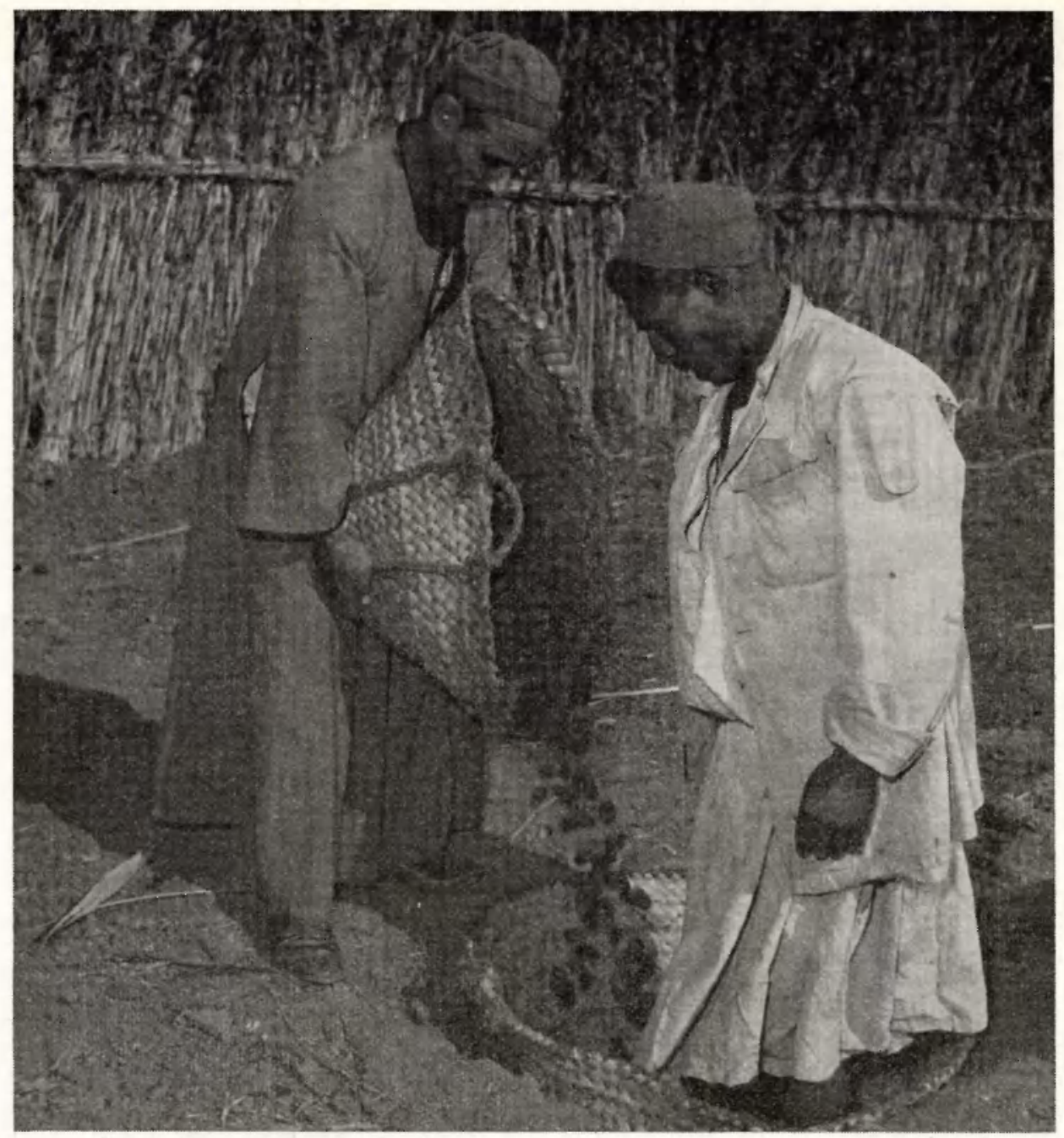

Fig. 3 Tramping dates in Baskets. (By Courtest of the Depalitment of hural. INJUSTIHES, EGYPT)

ation, provided they have been harvested at the proper stage of inaturity, i.e. when with an average sugar content of 70 to 80 percent and a moisture content inferior to 20 percent.

Nature is kind to Saudi Arabia and Iraq where the climatic conditions are such that most varieties can be allowed to ripen on the trees. In the coastal belts of Libya, however, dates mature on trees only during an exceptionally hot summer and when rains do not start too early. Therefore, modern processing, namely dehydrating is the answer to the Libyan problem, while in Iraq and Saudi Arabia some commercial varieties need additional moisture, i.e., a process known as hydration, in order to satisfy costumers' taste.

Sun-drying, widely practised, is the easiest and oldest method of preservation, and is the only method by which individual farmers can keep their crops for the future use of men and animals. 
Traditionally, dates are spread out directly on the earth, and sometimes on mats. During the drying period, they are turned around at intervals, and unavoidably collect dust, dirt, sand and other foreign matters. When they are sufficiently dry they are prepared for packing and storing. They are pressed into palm-leaf baskets with bare feet, and the greater the pressure the more the insects, always present to a certain extent together with their eggs and larvae, are wholly or partially killed. The possibility of oxidation also is reduced as there is less air circulating in the pressed mass. Well pressed dates can be kept much longer than loosely packed dates.

This method is, of course, quite unhygienic, and reminds one of dough kneading by feet, which used to be practised in some small European bakeries which could not afford to buy machines.

In all countries concerned the problem of date destruction by insects at all stages, i.e. on the tree, during harvesting, drying, packing, storage, causes considerable losses.

Spoilage during storage, due to a too high moisture content; is a particular problem for the dates of the Lybian coastal belt, and obviously this can only be avoided through artificial drying. In an attempt to solve this problem, an experimental pilot dehydrating plant was erected and has been successfully in operation for two successive seasons.

FAO Expert, Mr. V. H. W. Dowson, of the United Kingdom, who has had a wide experience with Iraqi and African dates, assisted in the erection and operation of this plant. It has been proved that, through the process of artificial dehydration, the preservatory quality of Libyan coastal dates can be greatly increased, and therefore a commercial plant was designed and put into operation at the end of 1955.

The increased amount of processed (dehydrated) dates will enable the Government to participate in the Libyan-UNICEF school-feeding program with a domestic food.

In the future it may also enable the Government to lay up a stock of dates, to be used when the grain crop fails in extra dry seasons. Fortunately, date palms never fail to produce.

In Saudi Arabia, with the help of Mr. Th. Carlson, from California, USA, two small processing and packing plants have been installed. A very attractive pack, which can be carried easily by hand, is processed particularly for the use of pilgrims to Mecca.

In contrast with Libya, where dates are mainly for home consumption, some 300,000 tons are exported per year from Iraq. In this country, there are several packing houses already in operation, and it has been considered necessary to instal a modern processing and packing plant in order to avoid the loss of further export markets due to the use of unhygienic and unsuitable methods of processing and packing.

FAO expert Mr. FrANK H. Winter, also from California, USA, is advising and assisting the working of two modern plants, one located in Baghdad and the other in Basrah, both of which were in operation in 1955.

These plants have a capacity of 5,000 tons each, which is 10,000 tons of dates per season if the work is carried out in only one shift. They are operated under the supervision and guidance of the Date Association, a governmental body, and they will be of particular assistance to the many date growers and 
packers, the majority of them small holders by so processing and packing their crops as to make them suitable for the export market.

The processing routine in these factories is as follows:

1 fumigation with methylbromide upon arrival of the dates to the factory;

2 washing by spraying followed by grading on moving rubber belts ;

3 packing, either in attractive small packs, cellophane wrapped, boxes or in bulk;

4 finally, prior to shipment, boxes and bulk are stored under methylbromide.

These factories are also equipped for hydration process, and the utilization of by-products.

Mr. WiNTER has also been advising for a short period in 1955 the Government of Sudan.

The Government of Pakistan have also requested FAO's advice on date processing and packing.

Mr. GFonge D. Kapsiotts, of Greek nationality, recently joined Mr. WinTER in Iraq, to advise and assist in the organization of a routine laboratory for hygienic control during the various stages of the process. He also will work on the development of a program for the utilization of by-products, syrups, culls or rejected dates, pits (stones), and so on, the latter mixed with other vegetable waste material to be used as animal feed.

A large part of the experts' time in all these assignments, is used to train the nationals of the country. Although the Baghdad plant does not yet operate at full capacity, its speed of operation has been increased regularly. The workers, who also clean the factory daily and maintain equipment and machinery, work with a fine spirit and are very proud of the plant. Early in 1956 a Dutch Junior Technician, Mr. W. H. BarReveld, is expected in Iraq to assist in the activities of FAO's date team.

\section{FAO'S PRojeCtS IN RUBBER PROCESSING}

Mr. W. Lloyn, from the United Kingdom, has been in Thailand for the past four years advising the Government on rubber planting and processing. Recently, he has also paid a short visit to the Union of Burma to advise the Government on its rubber problems.

Rubber is grown in Southern Thailand almost entirely by small holders, and improvement therefore can logically be expected through the medium of cooperatives, who collect latex centrally, process it into rubber and market it.

The expert, therefore, has advised and assisted in the erection and operation of improved small to medium sized cooperative factories, supplied with adequate equipment and machinery. This could be effected in those areas where a sufficient number of small-holders could be persuaded of the value of working together. However, the almost classic type of small processing unit, known over the Far East and consisting of a shed in which a few coagulating pans and one hand operated roller are the only equipment, will continue to be used by those groups of smallholders who prefer to have their own private "factory".

Several well-equipped cooperative factories are already in operation, and owing to the installation of modern equipment and machinery, the quality of processed rubber has remarkably increased. The percentage of "off grades" based on export figures, dropped from 20 percent in 1952 to about 10 percent in 1953, and is still decreasing. 


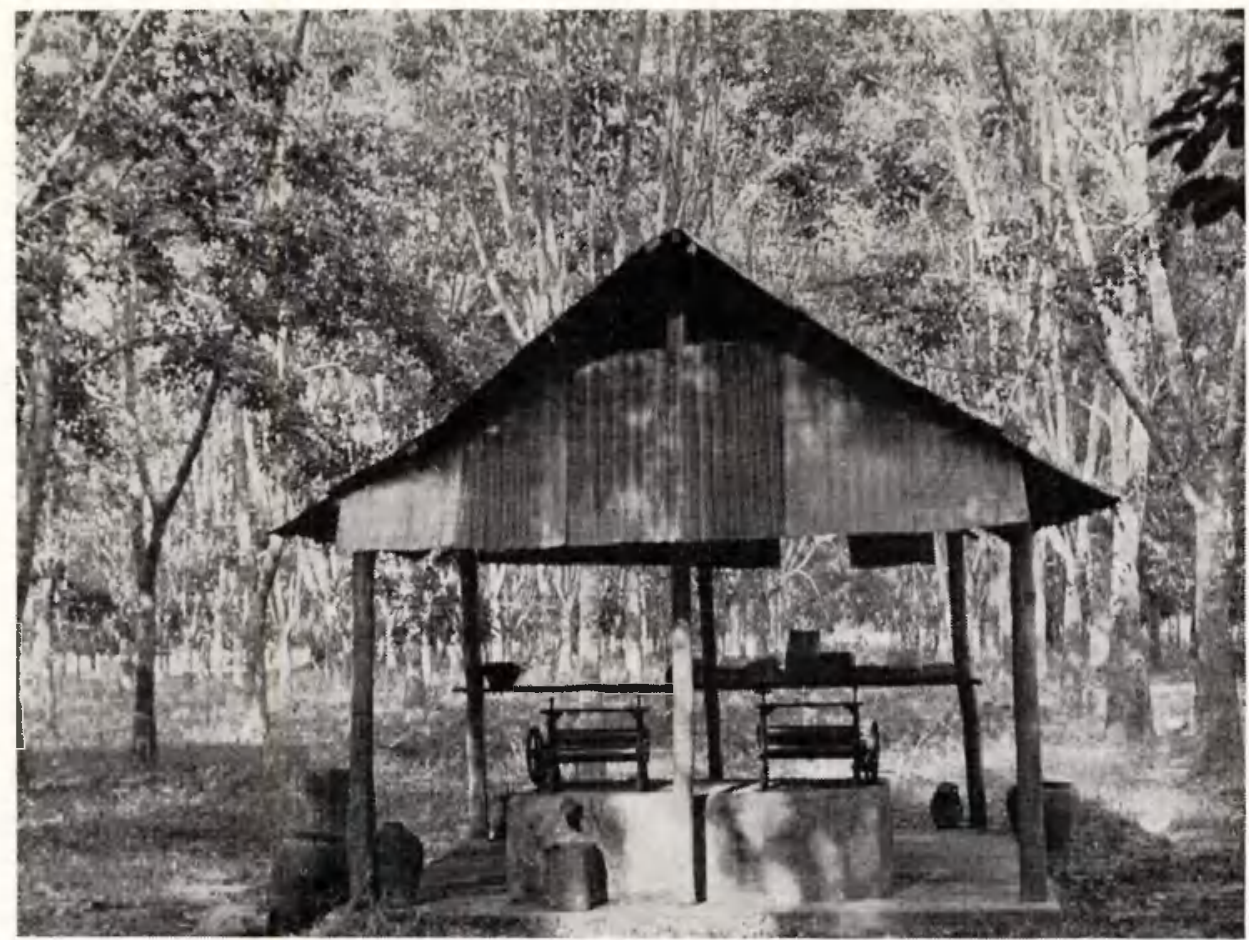

Fig. 4 Simple rubber processing Shed (Southern Thail.and)

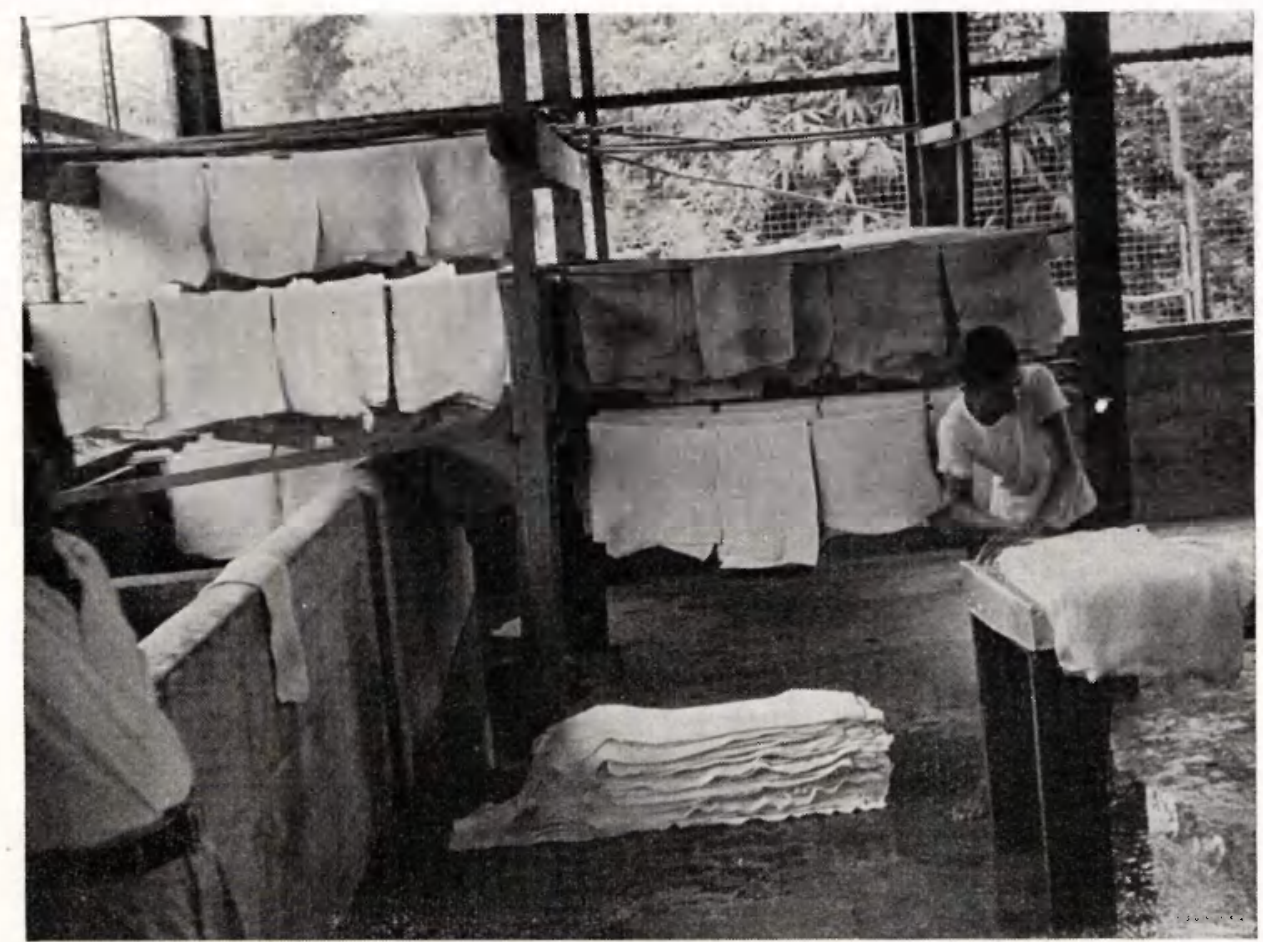

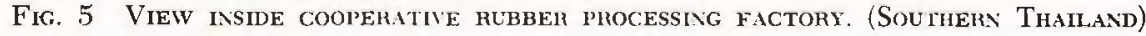


On the whole, these cooperative factories did not show such a great profit in 1954 as was expected, owing to difficulties inherent to cooperative programs. However, the smallholders' profit has been considerably increased, as they have received, due to the improved quality, top market prices for practically all their latex.

The cooperative officer, EuA NA Songkia, who received training under FAO's fellowship program, is now working to improve the cooperative activities. The equipment and machinery for this project were supplied by the American Aid Program. It is regrettable that, for several reasons, the re-planting schedule is somewhat retarded, particularly since rubber is becoming a great source of dollar income for the country.

A rubber testing station was recently opened in Kohong, near the Malayan border and FAO has sent Mr. C. E. Mellens (United Kingdom) to that Station in order to advise and assist in the development of this side of the program.

This station will prove of great help in order to process and to test technically classified rubber in accordance with internationally accepted standards. At a further stage of the program Mr. Melders will also look after the manufacture of foam latex, powdered rubber (or its equivalent) and the development of industries which use rubber as a raw material, (tyres, rubber goods and so on).

A regular contact is maintained with internationally recognised rubber institutes, particularly in Malaya.

In conclusion it must be emphasized that activities such as those discussed in this paper contribute to the general welfare of only a few of those who still suffer from want. It is hoped, however, that much more will be done in the future, for the human element in these programs has to be recognised as the most important force.

While such work is a common responsibility of all countries, it is hoped that enthusiasm and belief in this particular facet of the work of FAO has been and will continue to be fostered in the less developed areas of the world.

\section{SELECTED REFERENCES}

Beukering, J. A. van : Social, economic and cultural background of agricultural extension in less developed countries. Methods of agricultural extension, p. 18, Wageningen 1953.

Brand, W. : Het streven van de economisch onontwikkelde landen naar een hogere levensstandaard. Thesis, Amsterdam 1954.

FAO Agricultural Development Papers: See Table 1.

FAO Agricultural Studies: See Table 1.

Fledderus, M. L. and Mary van Kleech : Technology and Livelihood: an Enquiry into the Changing Technological Basis for Production as Affecting Employment and Living Standards, New York, Russell Sage Foundation, 1944.

Geus, J. DE : Rural Youth in a Changing World. World Assembly of Youth. Way Forum No. 13, April 1955.

HAMBdme, Gove : The Story of FAO. D. van Nostrand Company, Inc., 1955.

Henderson, S. M. : Agricultural Processing Engineering. Agricultural Engineering, 35 (1954) 333.

- - and R. L. Perry : Agricultural Process Engineering, New York, 1955.

Hurst, W. M. : Industrial Application of Agricultural Engineering. Agricultural Engineering, $31(1950) 441$. 
Legrand, L. E. : Le Technicien Agricole et le Technicien d'Industrie. Confédération Internationale des Ingénieurs et Techniciens de l'Agriculture. Journées de la Technique Agricole. Techniques et Techniciens Agronomes dans le Monde Moderne, Paris, 30 Septembre-1 Octobre 1955.

Mandelbaum, K.: The Industrialization of Backward-areas. Monograph No, 2 of the Institute of Statistics, Oxford 1955.

Mead, Margaret : Cultural Patterns and Technical Change, Tension and Technology Series, UNESCO, 1953.

Ogburn, William Fieldeng (Editor) : Technology and International Relations, Chicago, 1949.

Opler, Morrus E. : Social Aspects of Technical Assistance in Operation. Tensions and Technology Series, UNESCO, 1954.

Phillips, Ralph W.: International Cooperation to Improve World Agriculture. The Scien tific Monthly, 79, No. 3, September 1954.

Pontatowski, M. : Les Problèmes Posés par l'Evolution Economique des Pays Sous-Developpés. Bulletin Economique et Social du Maroc. Vol. XVI, No. 56, 1952, No. 57, 1953.

Ruopp, Phrllips (Editor): Approach to Community Development. The Hague, W. van Hoeve Ltd., 1953.

Spicer, Edward H. : Human Problems in Technological Change : A Case Book, New York, Russel Sage Foundation, 1952.

UnITED Nations: The Expanded Program of Technical Assistance for Economic Development of Under-Developed Countries. The Technical Assistance Board, New York, 1953.

- - : Department of Economic and Social Affairs. Processes and Problems of Industrialization in Under-Developed Countries, New York, 1955.

WaHLEN, F. T.: Aus der Arbeit der Ernährungs- und Landwirtschafts-Organisation der Vereinigten Nationen (FAO) in den Wirtschaftlich zurückgebliebenen Gebieten. Schwetzerische Landwirtschaftliche Monatshefte, Heft 3 (1952).

YANG, HaIn-PAO: Fact Finding with Rural People. FAO Agricultural Development Paper No. 52, August 1955.

Yates, P. Lamartine: So bold an aim. Ten Years of International Cooperation Towards Freedom from Want. Food and Agriculture Organization of the United Nations, Quebec 145 - Rome 1955.

Zonkan, Maurice : Asia and the West, London, 1951. 


\section{UTTAR PRADESH scale: inch to 100 mites}

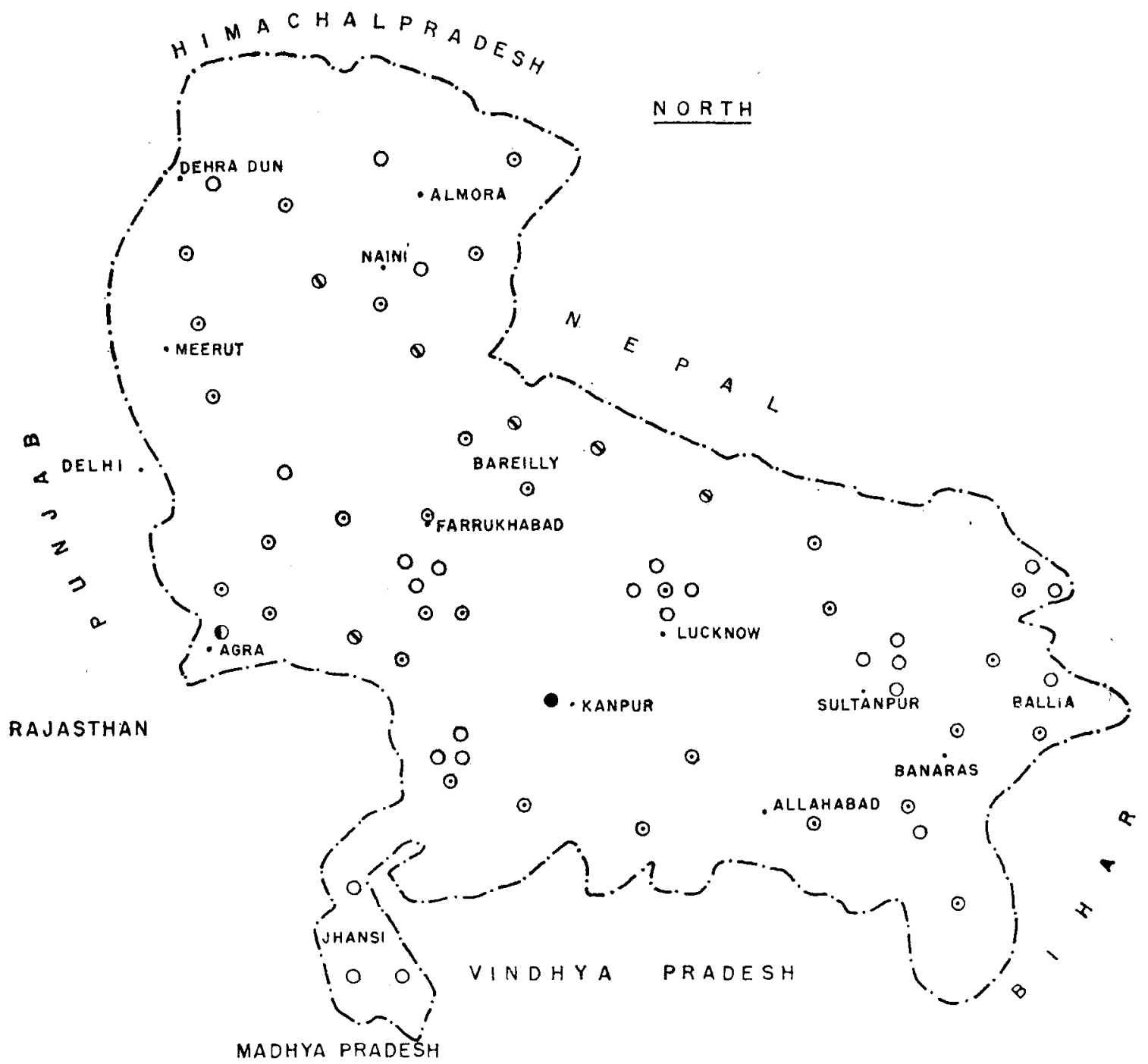

HIDE PRODUCTION PER ANNUM 2.500 .000

O RURAL hIDE FLAYING, CURING, CARCASSUTILISATION CENTRES

- RuRal tanNing centres.

1955-1956 Q CONCENTRATION CAMPS FOR USELESS CATTLE

- leather testing station. 
Table 1 Rural Welfare Branch. Agriculture Division.

Summary of Activities in the field of Processing of Agricultural Products and Rural Industries, up to the end of 1955 (Funds derived from the Regular Program) $\mathbf{E}=$ English $\quad \mathrm{F}=$ French $\quad \mathrm{S}=$ Spanish

1948 Meeting on Food Freezing and Refrigeration. Copenhagen, Denmark, 11-13 October 1948. (Financed under the UNRAA Transfer Fund).

1950 Tressler, Donald K. : Some Aspects of Food Refrigeration and Freezing (E). Agricultural Studies No. 12, November 1950.

1951 Ray, Luthen R. and Evert Beekman : Equipment for the Cleaning and Grading of Grains and Seeds (E.F.S.). Agricultural Development Paper No. 10, July 1951.

Ray, Luther R. and Evert Beekman :Equipment for the Processing of Tea (E.F.). Agricultural Development Paper No. 12, November 1951.

Ray, Luther R. and Evert Beekman: Equipment for the Tanning of Hides and Skins (E.F.S.). Agricultural Development Paper No. 13, December 1951.

1952 Wahlen, F. T. and A. D. Faunce : FAO's Participation in the Program of Technical Assistance of the United Nations and its Importance in the Development of Agriculture and Agricultural Industries in Under-developed Countries (E. summary F.). Paper presented at the "IX Congresso Internazionale Industrie Agrarie" Rome, 27 May1 June, 1952.

1953 Aten, A, A. D. Faunce and Luther R. RaY : Equipment for the Ginning of Cotton (E.S.). Agricultural Development Paper No. 25, March 1953.

Aten, A., A. D. Faunce and Luther R. Ray : Equipment for the Processing of Rice (E.F.S.). Agricultural Development Paper No. 27, March 1953.

Aten, A., A. D. Faunce and Luther R. Ray : Equipment for the Processing of Long Vegetable Fibers (E.F.S.). Agricultural Development Paper No. 26, April 1953.

1954 ATEN, A. : Problems connected with Agricultural Industrialization of Rural Areas and Technical Advisory Assistance (E. Summary F.S.). Paper presented at the "Xth Congreso Internacional de Industrias Agricolas" Madrid, 30 May-6 June 1954.

International Rice Commission. Report of the Fourth Session, Tokyo, Japan, 11-19 October 1954.

1955 Aten, A., R. Faraday Innes and E. Knew : Flaying and Curing of Hides and Skins as a Rural Industry (E.F.). Agricultural Development Paper No. 49, May 1955.

AteN, A.: FAO's Activities in Hides and Skins Improvement and Allied Matters (E.F.). Paper presented at the Congress of the International Hides and Allied Trades Improvement Society, Milano, 18-21 September 1955.

Holleman, L. W. J. and A. Aten : Processing of Cassava and Cassava Products in Rural Industries (E.). Agricultural Development Paper No. .... (early 1956). 
Table 2 Rural Welfare Branch. Agriculture Division.

Summary of Activities in the field of Processing of Agricultural Products and Rural Industries, showing the direct technical advisory assistance. up to the end of 1955. (Funds derived from the Expanded Technical Assistance Program). For details see Table 3

Underlined - in process

(x) - together with UNTAA and ILO

Subject

Handloom, weaving and spinning

Hides, skins and related matters

Rubber processing

Rubber testing and technology

Sugar processing

Rice Processing

Date processing and packing

Date technology, utilization of by-products . .

Tea processing

Silk Reeling

Rural Industries, general

Rural Industries Survey (x)

Fiber processing

Processing of agricultural products, general . .

Abattoirs and by-products processing .......

Refrigeration of agricultural products .......

Knife flaying demonstrations

Mechanical flaying demonstrations

Olive Oil processing
Country receiving direct technical advisory assistance

Ecuador, Egypt, India (Raj.), Mexico

Libya, India (U.P.), Ethiopia, Iraq, Egypt, Haiti, Philippines, Iran

Thailand, Burma (survey)

Thailand

El Salvador, Guatemala

Liberia, Ceylon, Burma, Paraguay, Venezuela, $\grave{P} a k i s t a n$, Thailand

Saudi Arabia, Libya, Iraq, Sudan (survey), Pakistan

Iraq

Iran

Burma, Afghanistan

Egypt, Bolivia, Syria, Jordan

Ceylon

Costa Rica, Ceylon

Colombia

Pakistan

Pakistan, Libya

Iraq, Egypt

Egypt

Israel 
Table 3 Rural Welfare Branch. Agriculture Division.

Chronological summary of activities in the field of processing of agricultural products and rural industries showing the direct technical advisory assistance up to the end of 1955. (Funds derived from the Expanded Technical Assistance Program). For short summary see Table 2

(x) - Reports, see Table 4

$\begin{aligned} & \text { Country receiving tech- } \\ & \text { nical advisory assistance }\end{aligned}$
Subject $\quad$ Year $\quad \begin{aligned} & \text { Expert and country } \\ & \text { of origin }\end{aligned}$

1951

\begin{tabular}{|c|c|c|c|}
\hline Ecuador & $\begin{array}{l}\text { Handloom weaving and } \\
\text { handspinning }\end{array}$ & $\begin{array}{l}\text { 3. } 1.51 / \\
\text { 6. } 8.52\end{array}$ & $\begin{array}{l}\text { Mrs. F. M. LA Grande } \\
\text { (American Indian) }\end{array}$ \\
\hline Ecuador & $\begin{array}{l}\text { Handloom weaving and } \\
\text { handspinning }\end{array}$ & $\begin{array}{l}\text { 19. } 2.51 / \\
18.9 .51\end{array}$ & $\begin{array}{l}\text { W. A. AMES } \\
\text { (U.S.A.) }\end{array}$ \\
\hline Libya & $\begin{array}{l}\text { Hides, skins and related } \\
\text { matters }\end{array}$ & $\begin{array}{c}17.9 .51 / \\
1.11 .53\end{array}$ & $\begin{array}{l}\text { R. FARADAY INNES }(x) \\
\text { (United Kingdom) }\end{array}$ \\
\hline India (U.P.) . & $\begin{array}{l}\text { Hides, skins and related } \\
\text { matters }\end{array}$ & $\begin{array}{l}24.10 .51 / \\
\text { continues }\end{array}$ & $\begin{array}{l}\text { F. H. Hoek }(x) \\
\text { (Netherlands) }\end{array}$ \\
\hline Pakistan ... & $\begin{array}{l}\text { Abattoir and by- } \\
\text { products processing }\end{array}$ & $\begin{array}{l}3.12 .51 / \\
-8.2 .53\end{array}$ & $\begin{array}{l}\text { R. W. HILL (x) } \\
\text { (United Kingdom) }\end{array}$ \\
\hline Thailand & Rubber Processing & $\begin{array}{l}10.12 .51 / \\
\text { continues }\end{array}$ & $\begin{array}{l}\text { W. LLoYD (x) } \\
\text { (United Kingdom) }\end{array}$ \\
\hline 1952 & & & \\
\hline Pakistan & $\begin{array}{l}\text { Refrigeration of agri- } \\
\text { cultural products }\end{array}$ & $\begin{array}{l}\text { 4. } 1.52 / \\
26.1 .53\end{array}$ & $\begin{array}{l}\text { E. WHALLEY (x) } \\
\text { (United Kingdom) }\end{array}$ \\
\hline El Salvador & Sugar processing & $\begin{array}{l}\text { 15. } 3.52 / \\
26.8 .52\end{array}$ & $\begin{array}{l}\text { W. Scotr (x) } \\
\text { (U.S.A.) }\end{array}$ \\
\hline Liberia & Rice procecssing & $\begin{array}{l}\text { 16. } 5.52 / \\
\text { 3. } 6.53\end{array}$ & $\begin{array}{l}\text { T. T. HoGAN (x) } \\
\text { (U.S.A.) }\end{array}$ \\
\hline Saudi Arabia...... & $\begin{array}{l}\text { Date processing and } \\
\text { packing }\end{array}$ & $\begin{array}{l}\text { 5. } 6.52 / \\
\text { 12. } 3.54\end{array}$ & $\begin{array}{l}\text { T. C. CARLSON (x) } \\
\text { (U.S.A.) }\end{array}$ \\
\hline $\operatorname{Iran}$ & Tea processing & $\begin{array}{l}\text { 10. } 6.52 / \\
\text { continues }\end{array}$ & $\begin{array}{l}\text { J. F. CouwENBerg } \\
\text { (Netherlands) }\end{array}$ \\
\hline Iran & Tea processing & $\begin{array}{l}\text { 13. } 7.52 / \\
5.11 .52\end{array}$ & $\begin{array}{l}\text { T. FUTAGAWA } \\
\text { (Japan) }\end{array}$ \\
\hline Iraq $\ldots \ldots$ & $\begin{array}{l}\text { Date processing and } \\
\text { packing }\end{array}$ & $\begin{array}{l}\text { 1. } 9.52 / \\
\text { continues }\end{array}$ & $\begin{array}{l}\text { Frank H. Winter (x) } \\
\text { (U.S.A.) }\end{array}$ \\
\hline Guatemala....... & Sugar processing & $\begin{array}{l}\text { 15. } 9.52 / \\
\text { 31. } 3.53\end{array}$ & $\begin{array}{l}\text { W. SCOTT } \\
\text { (U.S.A.) }\end{array}$ \\
\hline
\end{tabular}

1953

$\begin{array}{llll}\text { Libya } \ldots \ldots \ldots \ldots \ldots & \text { Date processing } & \begin{array}{l}4.1 .53 / \\ 1.1 .56\end{array} & \begin{array}{l}\text { V. H. W. Dowson } \\ \text { (United Kingdom) }\end{array} \\ \text { Ethiopia } \ldots \ldots \ldots \ldots & \begin{array}{l}\text { Hides and skins and } \\ \text { related matters }\end{array} & \begin{array}{l}1.2 .53 / \\ 22.3 .54\end{array} & \begin{array}{l}\text { C. M. Anderson (x) } \\ \text { (United Kingdom) }\end{array}\end{array}$


Table 3 (Cont.)

Country receiving technical advisory assistance

1954

Libya

Egypt

Burma

Iraq

Ceylon

Egypt

1955

Burma,$\ldots \ldots \ldots$.

Ceylon

Thailand

Haiti

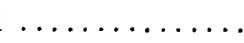

Iraq

Burma

Costa Rica

Sudan



Philippines . ........

Iraq

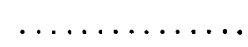

Irac

Paraguay

Colombi

India (Raj.)
Subject

Year

Hides and skins and related matters

Handloom weaving, agricultural implements, rural industries general

Silk reeling

Hides and skins and related matters

Rice processing survey

Hides and skins and related matters
20. $4.54 /$

8.11 .55

2. $9.54 /$ continues

27. $9.54 /$ continues

25.10.54/ 25.10 .55

$17.11 .54 /$

1. 6.55

6.12.54/ 2.12 .55
Expert and country of origin

C. F. Harding (x) (United Kingdom)

J. L. JANSEN

(Netherlands)

N. TANAKA

(Japan)

G. C. van Hoorn (x) (Netherlands)

F. Gariboldi (x) (Italy)

E. Dunnill $(x)$ (United Kingdom)
9. $3.55 /$

8. 4.55

3. $4.55 /$

3. 7.55 with TAA and ILO

Rubber testing and technology

Hides and skins and related matters

Date technology, utilization of by-products

Rice processing survey

Fiber processing

Date processing survey

Hides and skins and related matters

Knife flaying demonstrations

Hides and skins and related matters

Rice processing

Procecssing of agricultural products (general)

Processing of wool handloom weaving
11. 4.55 ; continues

12. $4.55 /$ continues

29. $5.55 /$ continues

2. 6.55 / 7.10 .55

23. 8.55 / continues

12. $9.55 /$

2.10 .55

$5.11 .55 /$ continues

7.11.55/ continues

8.11.55/ continues

$8.11 .55 /$ continues

15.11.55/ continues

17.12.55/ continues
W. LLOYD (x) (United Kingdom)

J. A. van Beukering ( $x$ ) (Netherlands)

C. E. Mellers (United Kingdom)

F. Steiner (Austria)

G. D. Kapsiotis (Greece)

F. GARIBOLdI (x) (Italy)

E. M. DE HoNDr (Netherlands)

F. H. WINTER ( $\mathrm{x}$ ) (U.S.A.)

E. Taussig (United Kingdom)

W. Dawson (United Kingdom)

C. F. Harding (United Kingdom)

T. T. Hogan

(U.S.A.)

E. K. E. HaLewijn (Netherlands)

J. Eshuis (Netherlands) 
Table 4 Rural Welfare Branch. Agriculture Division.

List of Final Reports to Governments (Restricted documents)

INNES, R. FAKADAY : Report to the Government of Libya on the Improvement in Flaying, Curing and Tanning of Hides and Skins. FAO Report No. 216, December 1953.

HoEk, F. H. : Interim Report to the Government of the State of Uttar Pradesh, India, on Improved Methods of Flaying, Curing, Tanning and Related Matters, March 1954, FAO $/ 54 / 3 / 1784$.

HiLl, R. W. : Report to the Government of Pakistan on a Slaughterhouse and By-Products Plant for Karachi. FAO Report No. 109, March 1953.

LLOYD, W.: Interim Report to the Government of Thailand on Rubber Processing and Related Matters, June 1953, FAO/53/6/5013.

Whallex, E. : Report to the Government of Pakistan on A Survey of Refrigeration Requirements of Pakistan with Special Emphasis on Seed Potato Storage. FAO Report No. 108, March 1953.

Scotr, Waxter : Report to the Government of El Salvador on The Sugar Industry. FAO Report No. 51, November 1952.

Hogan, T. T.: Report to the Government of Liberia on The Installation and Utilization of a Rice Processing Pilot Plant. FAO Report No. 289, August 1954.

Carlson, Theodore : Report to the Government of Saudi Arabia on The Establishment of Date Processing and Packing Plants. FAO Report No. 266, April 1954.

Winter, Frank H.: Interim Report to the Government of Iraq on Modernisation of the Date Processing and Packing Industry, September 1954. FAO/54/9/4803.

Anderson, C. M. : Report to the Government of Ethiopia on Improvement, Preparation and Processing of Hides and Skins. FAO Report No. 303, December 1954.

HARDrNG, C. F.: Report to the Government of Libya on Improvement of Flaying and Curing of Hides and Skins for Export. FAO Report No. 441.

Hoorn, G. C. van : Report to the Government of Iraq on Improvement of Flaying, Curing and Tanning of Hides and Skins. FAO Report No. ....

Gariboldi, F.: Report to the Government of Ceylon on The Rice Processing Industry. FAO Report No. 429, November 1955.

Dunsill, E. : Report to the Government of Egypt on Improvement of Hides and Skins. FAO Report No. ....

LLoYd, W. : Report to the Government of the Union of Burma on The Rubber Planting Industry. FAO Report No. 402, July 1955.

Beukering, J. A. van : Report to the Government of Ceylon on the Development of SmallScale Industries (UNTAA - ILO - FAO, together with D. H. F. Black, Chairman, A. A. Evans, G. Dearing and P. R. Balakrishnan), New York, September 1955.

Gariboldi, F.: Report to the Government of Burma on The Rice Processing Industry. FAO Report No. 442.

Winter, F. H. : Report to the Government of Sudan on Date Growing, Processing, Packing, and Marketing Problems. FAO Report No. 440. 
Table 5 Rural Welfare Branch. Agriculture Division.

Summary of fellowships training provided for FAO Member Countries in the field of Processing of Agricultural Products and Rural Industries, until the end of 1955 (Financed with ETAP funds)

\begin{tabular}{|c|c|c|c|}
\hline $\begin{array}{l}\text { Country receiving } \\
\text { fellowships }\end{array}$ & $\begin{array}{l}\text { Subject and number of } \\
\text { fellowships provided }\end{array}$ & $\begin{array}{l}\text { Country in which train- } \\
\text { ing was carried out }\end{array}$ & $\begin{array}{l}\text { Length of } \\
\text { training }\end{array}$ \\
\hline Ecuador & $\begin{array}{l}\text { Handloom weaving, } \\
\text { textile arts (2) }\end{array}$ & U.S.A. & 9 months \\
\hline El Salvador & Sugar technology (1) & $\begin{array}{l}\text { U.S.A., Trinidad, } \\
\text { Puerto Rico }\end{array}$ & 9 months \\
\hline Iran $\ldots$ & Tea processing (2) & Indonesia, India & 6 months \\
\hline Iraq $\ldots$ & $\begin{array}{l}\text { Date processing, packing, } \\
\text { marketing (1) }\end{array}$ & $\begin{array}{l}\text { England, Belgium, Ger- } \\
\text { many, France, Italy }\end{array}$ & 8 months \\
\hline Liberia . & $\begin{array}{l}\text { Rice processing, storage, } \\
\text { handling and administration } \\
\text { of rice mills, marketing for } \\
\text { paddy and rice (2) }\end{array}$ & Sierra Leone & 3 months \\
\hline Libya & $\begin{array}{l}\text { Hides and skins improvement, } \\
\text { tanning (1) }\end{array}$ & Egypt & 1 year \\
\hline Saudi Arabia ... & $\begin{array}{l}\text { Date processing and } \\
\text { packing (1) }\end{array}$ & Iraq & 6 months \\
\hline Thailand & $\begin{array}{l}\text { Rubber production, rubber } \\
\text { processing cooperatives }(3)\end{array}$ & $\begin{array}{l}\text { Japan, U.S.A., Hong- } \\
\text { kong, Indonesia, Malaya }\end{array}$ & 1 year \\
\hline Yugoslavia & $\begin{array}{l}\text { Refrigeration of agricultural } \\
\text { products, food processing } \\
\text { industry (1) }\end{array}$ & Denmark & 4 months \\
\hline
\end{tabular}

